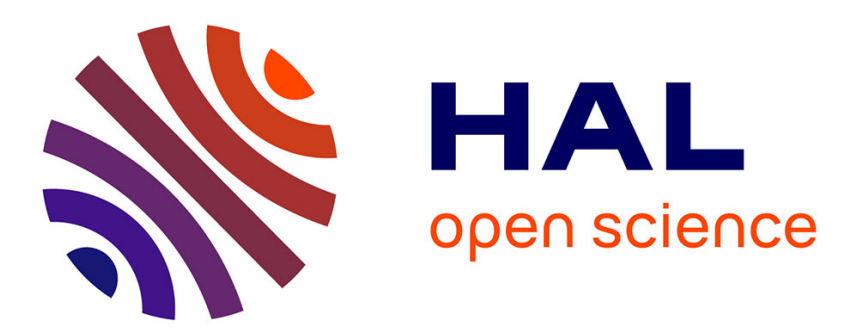

\title{
Amine oxidases of the quinoproteins family: Their implication in the metabolic oxidation of xenobiotics
}

Martine Largeron

\section{To cite this version:}

Martine Largeron. Amine oxidases of the quinoproteins family: Their implication in the metabolic oxidation of xenobiotics. Annales Pharmaceutiques Françaises, 2011, 69 (1), pp.53-61. 10.1016/j.pharma.2010.10.002 . hal-02384856

\section{HAL Id: hal-02384856 https://hal.science/hal-02384856}

Submitted on 5 Feb 2021

HAL is a multi-disciplinary open access archive for the deposit and dissemination of scientific research documents, whether they are published or not. The documents may come from teaching and research institutions in France or abroad, or from public or private research centers.
L'archive ouverte pluridisciplinaire HAL, est destinée au dépôt et à la diffusion de documents scientifiques de niveau recherche, publiés ou non, émanant des établissements d'enseignement et de recherche français ou étrangers, des laboratoires publics ou privés. 


\section{Elsevier Editorial System(tm) for Annales Pharmaceutiques Françaises Manuscript Draft}

\section{Manuscript Number: PHARMA-D-10-00031R1}

Title: Amine oxidases of the quinoproteins family : their implication in the metabolic oxidation of xenobiotics

Article Type: Séance thématique / Thematic session

Keywords: Copper amine oxidase; oxidative metabolism; xenobiotics; toxicity; inhibitor; enzyme mimic.

Corresponding Author: Dr martine largeron, Ph.D.

Corresponding Author's Institution: UMR 8638 CNRS-Université Paris Descartes

First Author: martine largeron, Ph.D.

Order of Authors: martine largeron, Ph.D.

Manuscript Region of Origin: FRANCE

Abstract: Copper amine oxidases (CuAOs) are ubiquitous enzymes which play a vital role in the physiology and pathology of mammals in controlling the metabolism of various primary monoamines, diamines and polyamines of endogenous or xenobiotic origin. CuAOs, which belong to the quinoproteins family, possess two cofactors: tightly bound CuII and a quinone residue which catalyzes the oxidative deamination of primary amines with concomitant production of aldehyde, ammonia and hydrogen peroxide through a " ping pong » mechanism. Interest in human enzymes of the CuAOs class has increased in recent years driven by the discovery that the human vascular adhesion protein-1 (VAP-1), which regulates leucocyte trafficking and glucose transport, is a $\mathrm{CuAO}$ enzyme. The activities of $\mathrm{CuAOs}$ are increased in various human disorders, such as diabetes, Alzheimer's disease and many inflammation-associated diseases leading to the overproduction of toxic metabolites, especially hydrogen peroxide and aldehyde compounds. As most consequences are pathological, effective and selective inhibitors of $\mathrm{CuAOs}$ should be of great interest as therapeutic agents. Nevertheless, the utilization of $\mathrm{CuAOs}$ to generate enzymatic toxic products into cancer cells for selective in situ killing deserves to be considered in cancer therapy. This paper briefly highlights recent progress in the study of physiological, pathological and molecular aspects of CuAOs in mammals. Furthermore, a small molecule that mimics the metabolic activity of CuAOs toward endogenous and exogenous amines is described because it could be used as a surrogate of enzymes for a preliminary screening of potential inhibitors of $\mathrm{CuAO}$ enzymes.

Suggested Reviewers:

Opposed Reviewers: 
Amine oxidases of the quinoproteins family : their implication in the metabolic oxidation of xenobiotics*

\author{
Amine-oxydases appartenant à la famille des \\ quinoprotéïnes : leur implication dans l'oxydation \\ métabolique des xénobiotiques*
}

\begin{abstract}
Martine Largeron
UMR 8638 associée au CNRS et à l'Université Paris Descartes, Synthèse et Structure de Molécules d'Intérêt Pharmacologique, Faculté des Sciences Pharmaceutiques et Biologiques, 4 avenue de l'Observatoire, 75270 Paris cedex 06, France
\end{abstract}

\begin{abstract}
*Communication présentée à l'Académie nationale de Pharmacie lors de la séance thématique du 19 mai 2010 «Importance de l'oxydation métabolique des médicaments et autres xénobiotiques : développements récents »

Adresse e-mail : martine.largeron@parisdescartes.fr (M. Largeron) ; Tél : (+) 331 53739646 ; Fax : (+) 33144073588.
\end{abstract}




\section{Abstract}

Copper amine oxidases (CuAOs) are ubiquitous enzymes which play a vital role in the physiology and pathology of mammals in controlling the metabolism of various primary monoamines, diamines and polyamines of endogenous or xenobiotic origin. CuAOs, which belong to the quinoproteins family, possess two cofactors: tightly bound $\mathrm{Cu}^{\mathrm{II}}$ and a quinone residue which catalyzes the oxidative deamination of primary amines with concomitant production of aldehyde, ammonia and hydrogen peroxide through a «ping pong » mechanism. Interest in human enzymes of the $\mathrm{CuAOs}$ class has increased in recent years driven by the discovery that the human vascular adhesion protein-1 (VAP-1), which regulates leucocyte trafficking and glucose transport, is a $\mathrm{CuAO}$ enzyme. The activities of $\mathrm{CuAOs}$ are increased in various human disorders, such as diabetes, Alzheimer's disease and many inflammation-associated diseases leading to the overproduction of toxic metabolites, especially hydrogen peroxide and aldehyde compounds. As most consequences are pathological, effective and selective inhibitors of $\mathrm{CuAOs}$ should be of great interest as therapeutic agents. Nevertheless, the utilization of $\mathrm{CuAOs}$ to generate enzymatic toxic products into cancer cells for selective in situ killing deserves to be considered in cancer therapy. This paper briefly highlights recent progress in the study of physiological, pathological and molecular aspects of $\mathrm{CuAOs}$ in mammals. Furthermore, a small molecule that mimics the metabolic activity of $\mathrm{CuAOs}$ toward endogenous and exogenous amines is described because it could be used as a surrogate of enzymes for a preliminary screening of potential inhibitors of $\mathrm{CuAO}$ enzymes. 


\title{
Keywords
}

Copper amine oxidase; oxidative metabolism; xenobiotics; toxicity; inhibitor; enzyme mimic.

\begin{abstract}
Abbreviations
CuAOs, copper amine oxidases; VAP-1, vascular adhesion protein-1; AOs, amine oxidases; MAOs, monoamine oxidases; SSAOs, semicarbazide-sensitive amine oxidases; PAOs, polyamine oxidases; FAD, flavine adenine dinucleotide; DAOs, diamine oxidases; LOs, lysyl oxidases; TPQ, topaquinone; LTQ, lysine tyrosylquinone, ROS, reactive oxygen species; PrAOs, primary amine oxidases; AGEs, advanced-glycation end products; BSAO, bovine serum amine oxidase
\end{abstract}

\section{Résumé}

Les enzymes amine-oxydase à cuivre (CuAOs) sont des enzymes ubiquitaires qui jouent un rôle essentiel chez les mammifères, tant au plan physiologique que pathologique, puisqu'elles contrôlent le métabolisme de diverses monoamines primaires, diamines et polyamines, d'origine endogène ou exogène. Les CuAOs, qui appartiennent à la famille des quinoprotéïnes, possèdent deux cofacteurs : un ion cuivrique et un résidu quinonique qui catalyse la désamination oxydante des amines primaires avec production concomitante d'aldéhydes, ammoniac et peroxyde d'hydrogène au travers d'un mécanisme «ping pong ». Récemment, un intérêt particulier a été porté à la famille des CuAOs humaines depuis la découverte de leur identité avec la protéine d'adhésion vasculaire humaine (VAP-1), qui joue un rôle régulateur dans la circulation des leucocytes et l'assimilation du glucose. Dans de 
nombreuses pathologies tels que le diabète, la maladie d'Alzheimer et les maladies inflammatoires, l'activité des CuAOs est accrue et conduit à une surproduction de métabolites toxiques, en particulier de peroxyde d'hydrogène et d'aldéhydes. Comme la plupart des conséquences sont pathologiques, la recherche d'inhibiteurs efficaces et sélectifs de CuAOs présente un intérêt en thérapeutique. Néanmoins, l'utilisation des $\mathrm{CuAOs}$ pour générer des produits toxiques, peroxyde d'hydrogène et aldéhydes, à l'intérieur des cellules cancéreuses, ouvre de nouvelles perspectives en thérapie anticancéreuse. Cet article décrit brièvement les progrès récemment réalisés dans la connaissance de la physiologie, de la pathologie et des mécanismes moléculaires des $\mathrm{CuAOs}$ chez les mammifères. De plus, une petite molécule qui mime l'activité métabolique des $\mathrm{CuAOs}$ envers les amines primaires, endogènes et exogènes, est présentée dans la mesure où elle pourrait être utilisée pour sélectionner de nouveaux inhibiteurs d'enzymes CuAOs.

\section{Mots Clés}

Amine oxydase à cuivre; métabolisme oxydatif; xénobiotiques; toxicité; inhibiteur; mime d'enzyme. 


\section{Introduction}

The implication of amine oxidases (AOs) in the oxidative metabolism of xenobiotic amines in humans has been largely neglected in the past [1], exclusive of studies concerning the metabolism of xenobiotics by mitochondrial monoamine oxidases (MAOs) $\mathrm{A}$ and $\mathrm{B}$, since these enzymes have been considered for a long time as targets for inhibition [2]. Interestingly, when MAO A and MAO B activities were completely blocked by an irreversible inhibitor, an enzymatic activity able to selectively oxidize primary amines remained in mammalian tissues [3-5]. The sensitivity of these novel enzymes to inhibition by semicarbazide led to refer them as semicarbazide-sensitive amine oxidases (SSAOs). Then, the superfamily of AOs was divided into two main categories: one class, which encompasses MAOs (A and B) (EC 1.4.3.4) and polyamine oxidases (PAOs), is characterized by the presence of flavine adenine dinucleotide (FAD) as the redox cofactor (Fig. 1) [6,7]. The second class is represented by $\mathrm{CuAOs}$ enzymes which possess tightly bound $\mathrm{Cu}^{\mathrm{II}}$ and a quinone residue as the redox cofactor [8,9]. This class, which belongs to the quinoproteins family, not only includes SSAOs, which are located in plasma membranes of various tissues and in blood plasma, but also intracellular diamine oxidases (DAOs) and lysyl oxidases (LOs). CuAOs (EC 1.4.3.6) use as redox cofactor the tyrosine-derived 2,4,5-trihydroxyphenylalanine quinone, also named topaquinone (TPQ) [10], at the exception of LOs (EC 1.4.3.13) whose active site has been identified as lysine tyrosylquinone (LTQ) (Fig. 1) [11].

$\mathrm{CuAOs}$ are ubiquitous enzymes isolated from mammals, many higher-order plants, fungi, yeasts and bacteria. Interest in human enzymes of the CuAOs class has increased in recent years driven by the discovery that the human vascular adhesion 
protein-1 (VAP-1), which regulates leucocyte trafficking and glucose transport, belongs to the CuAOs family [12].

This paper briefly highlights the progress recently achieved in understanding the involvement of mammalian $\mathrm{CuAOs}$ in the metabolic oxidation of xenobiotics, suggesting that the physiological role of CuAOs may be more diverse than expected. As most consequences are pathological, it is also highly desirable to obtain inhibitors with selectivity toward CuAOs over MAOs. In this respect, a potent orally active and selective inhibitor of CuAOs activity (LJP 1586), which is currently under investigation as a potential anti-inflammatory agent is presented. Furthermore, we describe a small molecule that mimics the metabolic activity of CuAOs toward endogenous and xenobiotic primary amines and that could be used as a surrogate of enzymes for a preliminary screening of potential inhibitors of human enzymes.

\section{Amine substrates of mammalian CuAOs}

CuAOs metabolize various primary monoamines, diamines and polyamines of endogenous or xenobiotic origin. However, some specificity is observed among the enzymes of this group [13]. For example, SSAOs catalyze the oxidative deamination of methylamine resulting from the metabolism of adrenaline and nicotine by MAO, and also present in tobacco smoke. Aminoacetone, a threonine and glycine catabolite, is also a specific substrate for SSAOs. DAOs preferably metabolize short-chain diamines such as histamine present in fish, cheese or alcoholic drinks, together with putrescine and cadaverine, both ubiquitous in food and also resulting from enzymatic decarboxylation of ornithine and S-adenosyl-methionine, while LOs oxidatively deaminates the $\varepsilon$-amino group of peptidyl-L-lysyl-peptide residues of 
collagen. Although CuAOs markedly differ from MAOs, they share some overlap in substrate specificity. For example, the non physiological benzylamine, which has been commonly used as a model of primary amine substrate, is a good substrate for both $\mathrm{CuAOs}$ and MAOs. Similarly, dopamine neurotransmitter, which can also be found in fruits and some vegetables, as well as tyramine greatly present in cheese, chicken liver and alcoholic drinks, are substrates for SSAOs, DAOs and MAOs.

To date, the involvement of CuAOs in the in vivo metabolism of marketed drug amines has received little attention [14]. Nevertheless, the loss of the amino group upon incubation of amlodipine, an antihypertensive agent, in dog and human plasma, is compatible with the implication of SSAO in amlodipine metabolism (Scheme 1) $[15,16]$. Similarly, the cytoprotective drug WR 1065 [2-(3aminopropylamino)ethanethiol)], administered as the thiophosphate derivative amifostine and utilized to protect tissues against the damaging effects of radiotherapy and chemotherapy, is converted by $\mathrm{CuAOs}$ to an aldehyde which spontaneously decomposes into cysteamine and acrolein (Scheme 2) [14, 17].

\section{Recent changes in nomenclature of CuAOs (2009)}

The term SSAO obviously is a confusing name because DAOs and LOs are also inhibited by semicarbazide, and it has often been used to refer specifically to AOs that are active toward primary amines. However, this has never been universally accepted and there are several publications on SSAOs that actually refer to DAOs $[13,18]$. To solve these problems, the Nomenclature Committee of the International Union of Biochemistry and Molecular Biology (IUBMB) has recently proposed to reclassify $\mathrm{CuAOs}$ (EC 1.4.3.6) as primary amine oxidases (PrAOs) (EC 1.4.3.21), 
the enzymes oxidizing primary monoamines with little or no activity toward diamines, and as diamine oxidases (DAOs) (EC 1.4.3.22), the enzymes oxidizing diamines such as histamine and also some primary monoamines. Both enzymes are inactive toward secondary and tertiary amines. These changes are now available at http://www.enzyme-database.org.

\section{Metabolic role of $\mathrm{CuAOs}$}

The role of $\mathrm{CuAOs}$ is to regulate levels of endogenous and xenobiotic primary mono- and polyamines, by catalyzing their oxidative deamination with the concomitant production of hydrogen peroxide, ammonia and aldehyde (Scheme 3). Each of these products is potentially harmful, since hydrogen peroxide can act as a source of reactive oxygen species (ROS) produced through the Fenton reaction, while ammonia and aldehyde products are known to be toxic in a number of systems [19-22]. Activities of plasma CuAOs are mostly increased in various human disorders, including type 1 and type 2 diabetes, congestive heart failure, atherosclerosis, liver cirrhosis, Alzheimer's disease and many inflammationassociated diseases leading to the overproduction of toxic metabolites especially hydrogen peroxide and aldehydes [23].

\section{Diabetes, Alzheimer's disease and CuAOs}

PrAOs catalyze the oxidative deamination of various endogenous substrates to produce aldehydes capable of inducing protein cross-linkage. Especially, the oxidative metabolism of methylamine and aminoacetone by PrAOs generate formaldehyde (Scheme 4, equation a) and methylglyoxal (Scheme 4, equation b) 
respectively as reactive metabolites which contribute to the formation of advancedglycation end products (AGEs), a phenomenon associated with vascular complications of diabetes [24]. These aldehydes are also capable of inducing protein cross-linking. Especially, they are able of enhancing the formation of $\beta$-amyloid misfolding oligomers and protofibrils, but also of increasing the size of the aggregates, two phenomena closely associated with Alzheimer's disease [25-28].

\section{Inflammatory diseases and $\mathrm{CuAOs}$}

The fact that PrAO/VAP-1 exerts both enzymatic and adhesion activities, and the strong correlation between its upregulation in many inflammatory conditions, make it an interesting therapeutic target. This interdependence of the adhesive and enzymatic functions of PrAO/VAP-1 provides the opportunity to develop enzyme inhibitors where the anti-inflammatory effects potentially would result from both blocking leucocytes migration and reducing the production of reactive metabolites. Furthermore, it would be highly desirable to obtain inhibitors with notable selectivity toward CuAOs over mitochondrial flavoproteins MAO A and MAO B. In this respect, a potent and selective inhibitor of PrAO activity (LJP 1207), that displayed anti-inflammatory activity in models of stroke, colitis and multiple sclerosis, was described. However, LJP 1207 was a hydrazine derivative and this class of compounds has potential for toxicity under prolonged administration [2931]. To avoid this problem, a structurally modified analog [LJP 1586, Z-3-fluoro-2(4-methoxybenzylallylamine)] with an amine functionality, is currently under investigation as a potential anti-inflammatory agent [32]. As shown in Table 1, LJP 1586 exhibits good specificity for inhibition of PrAO over both copper-dependent 
DAO and the FAD-dependent MAO A and MAO B. In addition, this orally active small molecule has demonstrated a good therapeutic window in adsorption, distribution, metabolism, excretion and toxicological studies performed to date.

\section{Cancer and $\mathrm{CuAOs}$}

The natural polyamines such as spermidine or spermine, formed from the decarboxylation products of ornithine and S-adenosyl-methionine, and ubiquitous in food, are also substrates for CuAO enzymes [33]. In cancerous cells, they are present at elevated levels as compared to normal tissues, because of enhanced putrescine synthesis from ornithine by ornithine decarboxylase, but also due to increased uptake of polyamines. Consequently, by delivering CuAOs [especially, bovine serum amine oxidase (BSAO)] into cancerous cells, the cytotoxic products of polyamines oxidation, hydrogen peroxide and aldehydes, could be produced in situ for selective killing of the same cells. For example, the oxidative deamination of spermidine produces an unstable aldehyde which spontaneously decomposes into the highly toxic acrolein and putrescine products [34] (Scheme 5). Interestingly, results obtained from the spermine oxidation by BSAO indicated that both hydrogen peroxide and acrolein were responsible for most of the observed cytotoxic effects on drug-sensitive and drug-resistant colon adenocarcinoma cells [35]. As drug-resistant cells were much more sensitive to the toxic enzymatic metabolites than the wild types, the utilization of CuAOs in anticancer therapy has been recently suggested as a promising strategy to overcome multidrug resistance of cancer [36-39]. 


\section{Catalytic mechanism of CuAOs}

Through the utilization of synthetic models of TPQ and LTQ cofactors and using benzylamine as the model substrate [40-44], it has been established that TPQ catalyzes the conversion of a primary amine into an aldehyde through a ping pong mechanism (Scheme 6) [45-47]. The reductive half reaction (ping), which involves amine oxidation into aldehyde, results in the reduction of $\mathrm{TPQ}_{\mathrm{ox}}$ into an aminoquinol form $\mathrm{TPQ}_{\mathrm{red}}$. A general consensus has been reached on the mechanism for this first half-reaction. The oxidative half reaction (pong) corresponds to the reduction of dioxygen to hydrogen peroxide, with concomitant formation of $\mathrm{TPQ}_{\mathrm{imq}}$. The final step under single turnover conditions is the hydrolysis of $\mathrm{TPQ}_{\mathrm{imq}}$ to regenerate $\mathrm{TPQ}_{\mathrm{ox}}[45]$. However, the rate of hydrolysis under single turnover conditions is too slow to be involved under the catalytic turnover conditions [48] and most likely $\mathrm{TPQ}_{\text {imq }}$ reacts directly with amine substrate through a transimination reaction leading to the Schiff base product bypassing $\mathrm{TPQ}_{\mathrm{ox}}$.

Although there is no question regarding the crucial role of $\mathrm{Cu}^{\mathrm{II}}$ ion in the biogenesis of TPQ from the autocatalytic post-translational oxidation of a tyrosine residue $[9,49,50]$, contrastingly, there is no consensus as to whether $\mathrm{Cu}^{\mathrm{II}}$ plays a redox role in catalysis, in other words whether the semiquinone $\mathrm{TPQ}_{\mathrm{sq}}$ is on the reaction pathway [51-57]. The role of $\mathrm{Cu}^{\mathrm{II}}$ in the oxidative half reaction has been partially clarified by studying copper-free and metal-substituted forms of CuAOs [58-60]. While the evidence from bacteria and plant amine oxidases supports transient reduction of copper, with $\mathrm{TPQ}_{\mathrm{sq}}$ being the species that preferentially reacts with dioxygen (see brackets in scheme 6) $[59,61,62]$, in the oxidative half reaction of mammalian amine oxidases, the electron transfer occurs directly between the 
aminoquinol form $\mathrm{TPQ}_{\mathrm{red}}$ and dioxygen, without change in the redox state of copper and without $\mathrm{TPQ}_{\mathrm{sq}}$ on the reaction pathway [60]. Nevertheless, copper could play a role in orienting the TPQ ring correctly in the active site.

\section{A small molecule that replicates the metabolic activity of CuAOs}

A few years ago, we described a small molecule $\mathbf{1}_{\mathbf{o x}}$ (Scheme 7) which behaves as an effective biomimetic catalyst for the oxidation of primary aliphatic monoamines, under metal- free conditions [63]. Note the structural analogy of $\mathbf{1}_{\mathbf{o x}}$ with the active form $\mathrm{TPQ}_{\mathrm{imq}}$ (Scheme 6). As $\mathbf{1}_{\mathbf{o x}}$ is an unstable $o$-iminoquinone species, it is generated in situ through an electrochemical oxidation process. The catalytic cycle produced the reduced catalyst $\mathbf{1}_{\text {red }}$ and $N$-alkylidenealkylamine as the product of amine oxidation. This process is the analog of the ping pong mechanism above described for the $\mathrm{CuAO}$ enzymes, but $\mathrm{N}$-alkylidenealkylamine was evidenced instead of aldehyde, because methanol was used as the solvent in place of aqueous solution. Consequently, no hydrolysis into aldehyde took place during the catalytic process.

This biomimetic electrocatalytic system displayed two features that are most often associated with enzymatic systems: (a) the reaction was enhanced through the participation of 1-acetyl and 2-hydroxyl substituents as they prevented the competing formation of Michael adducts; (b) the presence of the active 2-hydroxyl group, which was engaged in an intramolecular hydrogen bond with the imine nitrogen to form a highly reactive Schiff base cyclic transition state $\mathbf{1}$, $_{\mathbf{0 x}}$, constituted a prerequisite to the development of the catalytic process (Scheme 7) [64]. 
Using diverse endogenous and xenobiotic primary amines, we found that $\mathbf{1}_{\mathbf{o x}}$ presented the chemoselectivity observed for the CuAOs enzymes, that is high reactivity with unbranched primary amines and with the primary amino group of diamines and polyamines (Table 2). Overall, the electrocatalytic system $\mathbf{1}_{\mathbf{o x}}$ mimics not only the metabolic activity of PrAO enzymes, as high catalytic performances have been observed with primary monoamines (benzylamine, aminoacetone, propylamine and methylamine) and the terminal primary amino group of spermidine, but also that of DAOs as shown by the data obtained with putrescine, and to a lesser extent histamine [65]. Contrary to FAD-dependent amine oxidases, no activity was observed with secondary and tertiary amines (Table 3 ). Finally, a last question emerges whether selective CuAOs inhibitors such as LJP 1586 can also prevent the activity of the electrocatalyst $\mathbf{1}_{\mathbf{o x}}$. This study is currently envisioned in our laboratory because, in the affirmative, this small molecule might be used for a preliminary screening of potential inhibitors of $\mathrm{CuAO}$ enzymes. 


\section{Conclusions}

Interest in $\mathrm{CuAOs}$ has greatly increased in recent years, especially since the discovery that vascular adhesion protein 1 belongs to the CuAOs family. Thus, it has been established that CuAOs play a vital role in the physiology and pathology of mammals in controlling the metabolism of various primary monoamines, diamines and polyamines of endogenous or xenobiotic origin. As most consequences are pathological, effective inhibitors of $\mathrm{CuAOs}$ are of current interest because of their desired applications as therapeutic agents. We can now expect clinical study results that show whether control of CuAOs activity may serve as a new tool for treating various diseases. In this respect, the same toxic metabolites, formaldehyde and methylglyoxal, derived from CuAOs-mediated deamination of methylamine and aminoacetone respectively, cause proteins to aggregate and to crosslink, modifications which originate Alzheimer's disease and diabetes. This is consistent with recent studies providing strong evidence that Alzheimer's disease represents a form of diabetes that selectively involves the brain, hence the designation of Alzheimer's disease as "type 3 diabetes" [66,67]. Finally, CuAOs may be a potential target for the treatment of Alzheimer's disease and diabetes and no doubt the future of $\mathrm{CuAOs}$ research appears very promising.

\section{Conflict of interest}

None. 
References

[1] For a recent review see: Strolin Benedetti M, Tipton KF, Whomsley R. Amine oxidases and monooxygenases in the in vivo metabolism of xenobiotic amines in humans: has the involvement of amine oxidases been neglected? Fondam Clin Pharmacol 2007; 21: 467-479.

[2] Dostert P, Strolin Benedetti M, Tipton KF. Interactions of monoamine oxidase with substrates and inhibitors. Med Res Rev 1989; 9: 45-89.

[3] Lyles GA, Callingham BA. Evidence for a clorgyline-resistant monoamine metabolizing activity in the rat heart. J Pharm Pharmacol 1975; 27: 682-691.

[4] Roth JA, Gillis CN. Multiple forms of amine oxidase in perfused rabbit lung. J Pharmacol 1975;194:537-584.

[5] Lewinsohn R, Böhm KH, Glover V, Sandler M. A benzylamine oxidase distinct from monoamine oxidase $\mathrm{B}$ : widespread distribution in man and rat. Biochem Pharmacol 1978; 27: 1857-1863.

[6] Kalgutkar AS, Dalvie DK, Castagnoli N, Taylor TJ. Interactions of nitrogencontaining xenobiotics with monoamine oxidase (MAO) isozymes A and $\mathrm{B}$ : SAR studies on MAO substrates and inhibitors. Chem Res Toxicol 2001; 14: $1139-1162$.

[7] Fitzpatrick PF. Oxidation of amines by flavoproteins. Arch Biochem Biophys 2010; 493: 13-25.

[8] Klinman JP. The multi-functional topaquinone copper amine oxidases. Biochim Biophys Acta 2003; 1647: 131-137.

[9] Suzuki S, Okajima T, Tanizawa K, Mure M. Cofactors of amine oxidases. Copper ion and its substitution and the 2,4,5-trihydroxyphenylalanine 
quinone. In Floris G, Mondovi B, eds. Copper Amine Oxidases. Structures, Catalytic Mechanisms, and Role in Pathophysiology. New York: CRC Press; 2009. p. 19-38.

[10] Janes SM, Mu D, Wemmer D, Smith AJ, Kaur S, Maltby D, Burlingame AL, Klinman JP. A new redox cofactor in eukaryotic enzymes : 6-hydroxydopa at the active site of bovine serum amine oxidase. Science 1990; 248: 981-987.

[11] Wang SX, Mure M, Medzihradszky KF, Burlingame AL, Brown DE, Dooley DM, Smith AJ, Kagan HM, Klinman JP. A crosslinked cofactor in lysyl oxidase: redox function for amino acid side chains. Science 1996; 273: 10781084.

[12] Jaakkola K, Jalkanen S, Kaunismäki K, Vänttinen E, Saukko P, Alanen K, Kallajoki M, Voipio-Pulkki LM, Salmi M. Vascular adhesion protein-1, intercellular adhesion molecule-1 and P-selectin mediate leukocyte binding to ischemic heart in humans. J Am Coll Cardiol 2000; 36: 122-129.

[13] Boyce S, Tipton, KF, O’Sullivan MI, Davey, GP, Motherway Gildea M, McDonald AG, et al. Nomenclature and potential functions of copper amine oxidases. In Floris G, Mondovi B, eds. Copper Amine Oxidases. Structures, Catalytic Mechanisms, and Role in Pathophysiology. New York: CRC Press; 2009. p. 5-17.

[14] Tipton KF, Strolin Benedetti M. Amine oxidases and the metabolism of xenobiotics. In Ioannides C, ed. Enzyme systems that metabolize drug and other xenobiotics. John Whiley \& Sons Ltd; 2002. p. 95-146.

[15] Beresford AP, Macrae PV, Stopher DA. Metabolism of amlodipine in the rat and the dog: a species difference. Xenobiotica 1988; 18: 169-182. 
[16] Beresford AP, McGiney D, Humphrey MJ, Macrae PV, Stopher DA. Metabolism and kinetics of amlodipine in man. Xenobiotica 1988; 18: 245254.

[17] Meier T, Issels RD. Degradation of 2-(3-aminopropylamino)-ethanethiol (WR 1065) by $\mathrm{Cu}$-dependent amine oxidases and influence on glutathione status of Chinese hamster ovary cells. Biochem Pharmacol 1995; 50: 489 496.

[18] Boobis A, Watelet JB, Whomsley B, Strolin Benedetti M, Demoly P, Tipton KF. Drug interactions. Drug Metab Rev 2009; 41: 486-527.

[19] Lyles GA. Mammalian plasma and tissue-bound semicarbazide-sensitive amine oxidases: biochemical, pharmacological and toxicological aspects. Int. J Biochem Cell Biol 1996; 28: 259-274.

[20] Yu PH, Wright S, Fan EH, Lun ZR, Gubisne-Harberle D. Physiological and pathological implications of semicarbazide-sensitive amine oxidase. Biochim Biophys Acta 2003; 1647: 193-199.

[21] Matyus P, Dajka-Halasz B, Földi A, Haider N, Barlocco D, Magyar K. Semicarbazide-sensitive amine oxidase: current status and perspectives. Curr Med Chem 2004; 11: 1285-1298.

[22] O’Sullivan J, Unzeta M, Healy J, O’Sullivan M, Davey G, Tipton KF. Semicarbazide-sensitive amine oxidases: enzymes with quite a lot to do. NeuroToxicology 2004; 25: 303-315.

[23] Boomsma F, Bhaggoe UM, Van der Houwen AMB, Van den Meiracker AH. Plasma semicarbazide-sensitive amine oxidase in human (patho)physiology. Biochim Biophys Acta 2003; 1647: 48-54. 
[24] Obata T. Diabetes and semicarbazide-sensitive amine oxidase (SSAO) activity: a review. Life Sci 2006; 79: 417-422 and references therein.

[25] $\mathrm{Yu} \mathrm{PH}$. Involvement of cerebrovascular semicarbazide-sensitive amine oxidase in the pathogenesis of Alzheimer's disease and vascular dementia. Med Hypothesis 2001; 57: 175-179.

[26] Hernandez M, Esteban M, Szabo P, Boada M, Unzeta M. Human plasma semicarbazide sensitive amine oxidase (SSAO), $\beta$-amyloid protein and aging. Neuroscience Lett 2005; 384: 183-187.

[27] Chen K, Maley J, Yu PH. Potential implications of endogenous aldehydes in $\beta$-amyloid misfolding, oligomerization and fibrillogenesis. $\mathrm{J}$ Neurochem 2006; 99: 1413-1424.

[28] Jiang ZJ, Richardson JS, Yu PH. The contribution of cerebral vascular semicarbazide-sensitive amine oxidase to cerebral amyloid angiopathy in Alzheimer's disease. Neuropathol Appl Neurobiol 2008; 34: 194-204.

[29] Salter-Cid L, Wang E, O'Rourke A, Miller A, Gao H, Huang L et al. Antiinflammatory effects of a small molecule antagonist of SSAO/VAP-1. J Pharmacol Exp Ther 2005; 315: 553-562.

[30] Wang EY, Gao H, Salter-Cid L, Zhang J, Huang L, Podar EM, et al. Design, synthesis, and biological evaluation of semicarbazide-sensitive amine oxidase (SSAO) inhibitors with anti-inflammatory activity. J Med Chem 2006; 49: 2166-2173.

[31] O’Rourke A, Wang EY, Salter-Cid L, Huang L, Miller A, Podar EM, et al. Benefit of inhibiting SSAO in relapsing experimental autoimmune encephalomyelitis. J Neural Transm 2007; 114: 8456849. 
[32] O'Rourke A, Wang EY, Miller A, Podar EM, Scheyhing K, Huang L, et al. Anti-inflammatory effects of LJP 1586 [Z-3-fluoro-2-(4methoxybenzyl)allylamine hydrochloride], an amine-based inhibitor of semicarbazide-sensitive amine oxidase activity. J Pharmacol Exp Ther 2008; 324: 865-875.

Agostinelli E, Arancia G, Dalla Vedova L, Belli F, Marra M, Salvi M et al. The biological functions of polyamine oxidation products by amine oxidases: perspectives of clinical applications. Amino acids 2004; 27: 347-358.

[34] Lee Y, Sayre L. Reaffirmation that metabolism of polyamines by bovine plasma amine oxidase occurs strictly at the primary amino termini. J Biol Chem 1998; 273: 19490-19494.

[35] Calcabrini A, Arancia G, Marra M, Crateri P, Martone A, Agostinelli E. Enzymatic oxidation products of spermine induce greater cytotoxic effects on human multidrug-resistant colon carcinoma cells (LoVo) than on their wild-type counterparts. Int J Cancer 2002; 99: 43-52.

[36] Boomsma F, van der Meiracker AH, Toninello A. Plasma amine oxidases in various clinical conditions and in apoptosis. In Floris G, Mondovi B, eds. Copper Amine Oxidases. Structures, Catalytic Mechanisms, and Role in Pathophysiology. New York: CRC Press; 2009. p. 143-158.

[37] Toninello A, Pietrangeli P, De Marchi U, Salvi M, Mondovi B. Amine oxidases in apoptosis and cancer. Biochim Biophys Acta 2006; 1765: 1-13.

[38] Agostinelli E, Tempera G, Molinari A, Salvi M, Battaglia V, Toninello A, et al. The physiological role of biogenic amines redox reactions in 
mitochondria. New perspectives in cancer therapy. Amino acids 2007; $33: 175-187$.

[39] Agostinelli E, Tempera G, Viceconte N, Saccoccio S, Battaglia V, Grancara, $\mathrm{S}$, et al. Potential anticancer application of polyamine oxidation products formed by amine oxidase: a new therapeutic approach. Amino acids 2010; 38: $353-368$.

[40] Rinaldi AC, Rescigno A, Rinaldi A, Sanjust E. Modeling novel quinocofactors: an overview. Bioorg Chem 1999; 27: 253-288.

[41] Mure M, Klinman J.P, Model studies of topaquinone-dependent amine oxidases. 2. Characterization of reaction intermediates and mechanism. J Am Chem Soc 1995; 117: 8707-8718.

[42] Lee Y, Sayre LM. Model studies on the quinone-containing copper amine oxidases. Unambiguous demonstration of a transamination mechanism. J Am Chem Soc 1995; 117: 8707-8718.

[43] Ling KQ, Kim J, Sayre LM. Catalytic turnover of benzylamine by a model for the lysine tyrosylquinone (LTQ) cofactor of lysyl oxidase. J Am Chem Soc 2001; 123: 9606-9611.

[44] Mure M, Wang SX, Klinman JP. Synthesis and characterization of models compounds of the lysine tyrosyl quinone cofactor of lysyl oxidase. J Am Chem Soc 2003; 125: 6113-6125.

[45] Mure M, Mills SA, Klinman JP. Catalytic mechanism of the topaquinone containing copper amine oxidases. Biochemistry 2002; 41: 9269-9278.

[46] Mure M. Tyrosine-derived quinone cofactors. Acc Chem Res 2004; 37: 131139. 
[47] Dubois JL, Klinman JP. Mechanism of post-translational quinone formation in copper amine oxidases and its relationship to the catalytic turnover. Arch Biochem Biophys 2005; 433: 255-265.

[48] Hirota S, Iwamoto T, Kishishita S, Okajima T, Yamauchi O, Tanizawa K. Spectroscopic observation of intermediates formed during the oxidative halfreaction of copper/topaquinone containing phenylethylamine oxidase. Biochemistry 2001; 40: 15789-15796.

[49] Brazeau BJ, Johnson BJ, Wilmot CM. Copper-containing amine oxidases. Biogenesis and catalysis; a structural perspective. Arch Biochem Biophys 2004; 428:22-31.

[50] Kim M, Okajima T, Kishishita S, Yoshimura M, Kawamori A, Tanizawa K, Yamaguchi H. X-ray snapshots of quinone cofactor biogenesis in bacterial copper amine oxidase. Nat Struct Biol 2002; 9: 591-596.

[51] Dooley DM, Mcguirl MA, Brown DE, Turowski PN, Mcintire WS, Knowles PF. A Cu(I)-Semiquinone state in substrate-reduced amine oxidases. Nature 1991; 349: 262-264.

[52] Padiglia A, Medda R, Bellelli A, Agostinelli E, Morpurgo L, Mondovi B et al. The reductive and oxidative half-reactions and the role of copper ions in plant and mammalian copper-amine oxidases. Eur J Inorg Chem 2001; 3542.

[53] Pietrangeli P, Nocera S, Mondovi B, Morpugo L. Is the catalytic mechanism of bacteria, plant and mammal copper TPQ amine oxidases identical? Biochem Biophys Acta 2003; 1647: 152-156. 
Agostinelli E, Belli F, Dalla Vedova L, Longu S, Mura A, Floris G. Catalytic properties and the role of copper in bovine and lentil seedling copper/quinone-containing amine oxidases: controversial opinions. Eur J Inorg Chem 2005; 1635-1641.

[55] Juda GA, Shepard EM, Elmore BO, Dooley DM. A comparative study of the binding and inhibition of four copper-containing amine oxidases by azide: implications for the role of copper during the oxidative half-reaction. Biochemistry 2006; 45: 8788-8800.

[56] Shepard EM, Dooley DM. Intramolecular electron transfer rate between active-site copper and TPQ in Arthrobacter globiformis amine oxidase. J Biol Inorg Chem 2006, 11, 1039-1048.

[57] Welford RWD, Lam A, Mirica LM, Klinman JP. Partial conversion of hansenula polymorpha amine oxidase into a "plant" amine oxidase: implication for copper chemistry and mechanism. Biochemistry 2007; 46: 10817-10827.

[58] Mills SA, Goto Y, Su Q, Plastino J, Klinman JP. Mechanistic comparison of the cobalt-substituted and wild-type copper-amine oxidase from Hansenula polymorpha. Biochemistry 2002; 41: 10577-10584.

[59] Kishishita S, Okajima T, Kim M, Yamaguchi H, Hirota S, Suzuki S et al. Role of copper ion in bacteria copper amine oxidase: spectroscopic and crystallographic studies of metal-substituted enzymes. J Am Chem Soc 2003; 125: 1041-1055. 
[60] Mura A, Padiglia A, Medda R, Pintus F, Finazzi Agro A, Floris G. Properties of copper-free pig kidney amine oxidase: role of topa quinone. FEBS Lett 2006; 580: 4315-4324.

[61] Mukerjee A, Smirnov VV, Lanci MP, Brown DE, Shepard EM, Dooley DM et al. Inner-sphere mechanism for molecular oxygen reduction catalyzed by copper amine oxidases. J. Am. Chem. Soc. 2008; 130: 9459-9473.

[62] Shepard EM, Okonski KM, Dooley DM. Kinetics ans spectroscopic evidence that the $\mathrm{Cu}(\mathrm{I})$ semiquinone intermediate reduces molecular oxygen in the oxidative half-reaction of Arthrobacter globiformis amine oxidase. Biochemistry 2008; 47: 13907-13920.

[63] Largeron M, Neudörffer A, Fleury MB. Oxidation of unactivated primary aliphatic amines catalyzed by an electrogenerated 3,4-azaquinone species: a small-molecule mimic of amine oxidases. Angew Chem Int Ed 2003; 42: 1026-1029.

[64] Largeron M, Chiaroni A, Fleury MB. Environmentally friendly chemoselective oxidation of primary aliphatic amines by using a biomimetic electrocatalytic system. Chemistry-Eur J 2008; 14: 996-1003.

[65] Largeron M, Fleury MB, Strolin Benedetti M. A small molecule that mimics the metabolic activity of copper-containing amine oxidases (CuAOs) toward physiological mono- and polyamines. Org Biomol Chem 2010; 8: 37963800.

[66] de la Monte SM, Wands JRW. Alzheimer's disease is type 3 diabetesevidence reviewed. J Diabetes Sci Technol 2008; 2:1101-1113. 
[67] Rovner SL. Alzheimer's scary link to diabetes. Disruptions of insulin signalling and glucose regulation contribute to development of Alzheimer's disease. Chem. \& Engin. News 2009; 87(20): 42-46. 
Table 1 Selective inhibition of LJP 1586 for PrAOs

Inhibition sélective de LJP 1586 pour les PrAOs

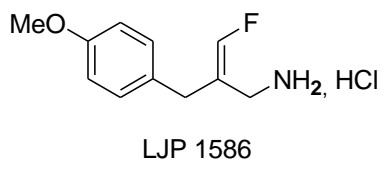

\begin{tabular}{llllll}
\hline $\begin{array}{l}\text { Human } \\
\text { Enzyme }\end{array}$ & UC PrAO & CHO PrAO & DAO & MAO A & MAO B \\
\hline $\mathrm{IC}_{50}(\mu \mathrm{M})$ & 0.027 & 0.043 & 96 & 98 & 2.2 \\
\hline $\begin{array}{l}\mathrm{UC}: \text { umbilical cord } \\
\mathrm{CHO}: \text { lysates of human PrAO-expressing CHO cells }\end{array}$
\end{tabular}


Table $2 \mathbf{1}_{\mathbf{o x}}$-mediated oxidation of CuAOs mono- and polyamine substrates Oxydation de mono- et polyamines substrats des CuAOs catalysée par $\mathbf{1}_{\text {ox }}$

\begin{tabular}{ll}
\hline Amine substrate & Catalytic efficiency $(\%)^{a}$ \\
\hline benzylamine & 100 \\
methylamine & $50^{b}$ \\
propylamine & 70 \\
aminoacetone & 94 \\
histamine & $20^{c}$ \\
putrescine & $88^{c}$ \\
spermidine & $94^{c}$
\end{tabular}

$\left(\mathbf{1}_{\text {red }}\right)=0.4 \mathrm{mM},($ amine substrate $)=20 \mathrm{mM}, \mathrm{MeOH}, \mathrm{rt}$,

Pt anode $(\mathrm{E}=+0.6 \mathrm{~V} v s \mathrm{SCE}) .{ }^{a}$ imine was isolated by converting to the 2,4-dinitrophenylhydrazone obtained after workup of the oxidized solution with 2,4-dinitrophenylhydrazine under aqueous acidic conditions. ${ }^{b}$ Volatile reaction products were partly lost during the anodic electrolysis. ${ }^{c}$ The $\mathrm{Pt}$ anode was replaced by a $\mathrm{Hg}$ anode $(\mathrm{E}=0.0 \mathrm{~V} v s \mathrm{SCE})$ because polyamines spontaneously attached to the Pt electrode surface. 
Table 3 Substrate specificity for amine oxidase enzymes in comparison with mimic $\mathbf{1}_{\mathbf{o x}}$

Comparaison de la spécificité de substrats des enzymes amine oxydases à celle du mime $\mathbf{1}_{\text {ox }}$

\begin{tabular}{lllll}
\hline Substrate & MAO A and B & PAO & CuAO & Mimic $\mathbf{1}_{\mathbf{0 x}}$ \\
& FAD & FAD & TPQ & \\
\hline $\begin{array}{l}\text { Primary amine } \\
\text { (unbranched) }\end{array}$ & $\times$ & - & $\times$ & $\times$ \\
$\begin{array}{l}\text { Secondary amine } \\
\text { Tertiary amine }\end{array}$ & $\times$ & - & - & - \\
$\begin{array}{l}\text { Diamine } \\
\begin{array}{l}\text { Polyamine } \\
\text { primary amino }\end{array}\end{array}$ & - & - & - & - \\
$\begin{array}{l}\text { group) } \\
\begin{array}{l}\text { Polyamine } \\
\text { secondary amino } \\
\text { group) }\end{array}\end{array}$ & - & - & $\times$ & $\times$ \\
\hline
\end{tabular}

$(\times)$ catalytic activity; (-) no catalytic activity 
Figure 1. Chemical structures of flavine adenine dinucleotide (FAD), topaquinone (TPQ) and lysine tyrosylquinone (LTQ) redox cofactors.

Structure chimique des cofacteurs redox, flavine adenine dinucléotide (FAD), topaquine (TPQ) et lysine tyrosylquinone (LTQ).

Scheme 1. Postulated metabolism of the antihypertensive agent amlodipine by SSAOs: the conversion of the amine function present in the amino side chain into an aldehyde group is compatible with the implication of SSAOs in amlodipine metabolism.

Métabolisme supposé de l'antihypertenseur amlodipine par les SSAOs : la conversion de la fonction amine présente sur la chaîne latérale aminée, en groupement aldéhyde, est compatible avec l'implication des SSAOs dans le métabolisme de l'amlodipine.

Scheme 2. Postulated metabolism of the cytoprotective drug amifostine (WR 1065). The primary amine function of WR 1065 is converted by CuAOs to an aldehyde which spontaneously decomposes into cysteamine and acrolein.

Métabolisme supposé du médicament cytoprotecteur amifostine (WR 1065). La fonction amine primaire du WR 1065 est convertie par les CuAOs en aldéhyde qui se décompose spontanément en cystéamine et acroléïne.

Scheme 3. Metabolic role of CuAOs : they regulate levels of endogenous and xenobiotic primary mono- and polyamines, by catalyzing their oxidative deamination with the concomitant production of hydrogen peroxide $\left(\mathrm{H}_{2} \mathrm{O}_{2}\right)$, ammonia $\left(\mathrm{NH}_{3}\right)$ and aldehyde $(\mathrm{CHO})$. Furthermore, $\mathrm{H}_{2} \mathrm{O}_{2}$ can act as a source of hydroxide radicals $\left(\mathrm{HO}^{\circ}\right)$ produced through the Fenton reaction.

Rôle métabolique des CuAOs : elles régulent les niveaux des mono- et polyamines primaires, endogènes et xénobiotiques, en catalysant leur désamination oxydante avec production concomitante de peroxyde d'hydrogène $\left(\mathrm{H}_{2} \mathrm{O}_{2}\right)$, ammoniac $\left(\mathrm{NH}_{3}\right)$ et 
aldéhyde (CHO). De plus, $\mathrm{H}_{2} \mathrm{O}_{2}$ peut agir comme source de radicaux hydroxyle $\left(\mathrm{HO}^{\circ}\right)$ produits via la réaction de Fenton.

Scheme 4. oxidative metabolism of methylamine into formaldehyde (a) and aminoacetone into methylglyoxal (b) by PrAOs

Métabolisme oxydant de la méthylamine en formaldéhyde (a) et de l'aminoacétone en méthylglyoxal (b) par les PrAOs

Scheme 5. oxidative metabolism of spermidine by PrAOs : the oxidative deamination of spermidine produces an unstable aldehyde which spontaneously decomposes into the highly toxic acrolein and putrescine products.

Métabolisme oxydant de la spermidine par les PrAOs : la désamination oxydante de la spermidine produit un aldéhyde instable qui se décompose spontanément en acroléïne, hautement toxique, et en putrescine.

Scheme 6. Proposed reaction mechanisms of CuAOs [9]: The reductive half reaction (ping), which involves amine oxidation into aldehyde, results in the reduction of $\mathrm{TPQ}_{\mathrm{ox}}$ into an aminoquinol form $\mathrm{TPQ}_{\mathrm{red}}$. The oxidative half reaction (pong) corresponds to the reduction of dioxygen to hydrogen peroxide, with concomitant formation of $\mathrm{TPQ}_{\mathrm{imq}}$. Most likely $\mathrm{TPQ}_{\mathrm{imq}}$ reacts directly with amine substrate through a transimination reaction leading to the Schiff base product bypassing $\mathrm{TPQ}_{\mathrm{ox}}$

Mécanisme réactionnel proposé pour les CuAOs [9]: La demi-réaction de réduction (ping), qui implique l'oxydation de l'amine en aldéhyde, entraîne la réduction de $T P Q_{o x}$ en une forme aminoquinol $T P Q_{\text {red. }}$ La demi-réaction d'oxydation (pong) correspond à la réduction de l'oxygène moléculaire en peroxyde d'hydrogène, avec formation simultanée de TPQ $Q_{i m q}$. Très vraisemblablement, $T P Q_{\text {imq }}$ réagit directement avec l'amine substrat selon une réaction de transimination pour donner la base de Schiff produit sans repasser par $T P Q_{o x}$. 
Scheme 7. $\mathbf{1}_{\mathbf{o x}}$-mediated catalytic oxidation of primary aliphatic amines into imines: the catalyst $\mathbf{1}_{\mathbf{o x}}$ is generated in situ through an electrochemical oxidation at a platinum anode, in methanol. The catalytic cycle produces the reduced catalyst $\mathbf{1}_{\text {red }}$ and $N$ alkylidenealkylamine as the product of amine oxidation.

Oxydation d'amines aliphatiques primaires en imines catalysée par $\mathbf{1}_{\text {ox }}$ : le catalyseur $1_{\text {ox }}$ est généré in situ par oxydation électrochimique, à une anode de platine, dans le méthanol. Le cycle catalytique produit la forme réduite du catalyseur $\mathbf{1}_{\text {red }}$ et une $N$-alkylidènealkylamine comme produit d'oxydation de l'amine. 
Figure 1
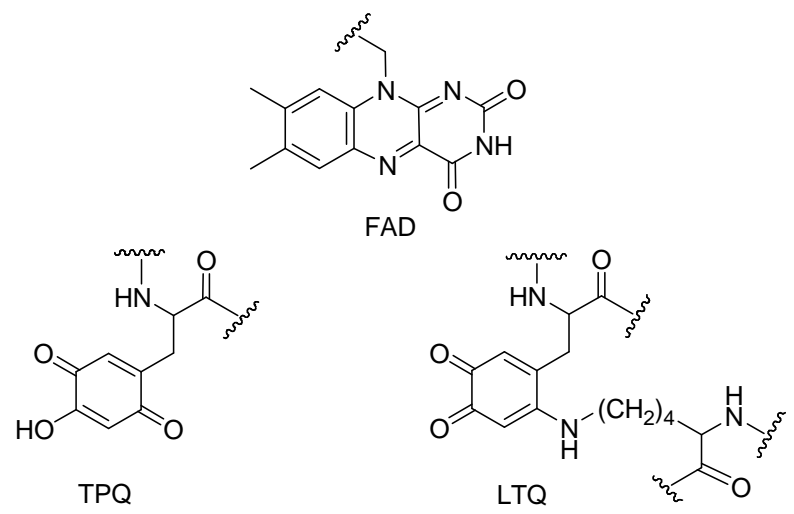

Figure 1 


\section{Scheme 1}

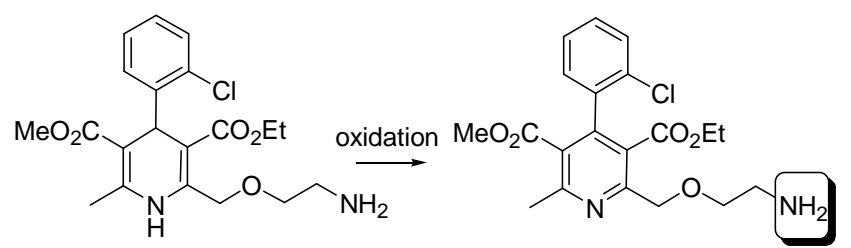

Amlodipine

SSAO<smiles>CCOC(=O)c1c(COC(=O)COC(=O)Cc2c(C)nc(COCC=O)c(-c3ccccc3Cl)c2-c2ccccc2Cl)nc(C)c(COCC(=O)O)c1OCC</smiles>

ALDH: aldehyde dehydrogenase $A O$ : aldehyde oxidase

Scheme 1 
Scheme 2

Scheme 2

acrolein cysteamine

spontaneous

decomposition

$\mathrm{H}_{2} \mathrm{~N} \frown \mathrm{SH}$

cysteamine

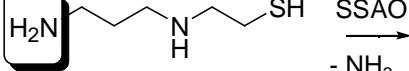

WR 1065
$\mathrm{O}_{\mathrm{H}} \sim \mathrm{SH}$ 
Scheme 3

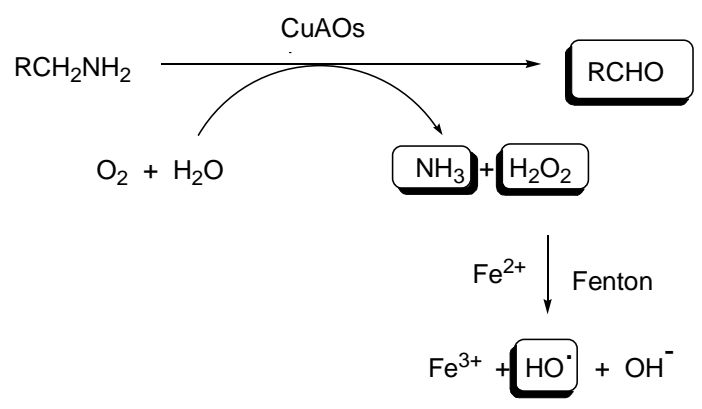

Scheme 3 
Scheme 4

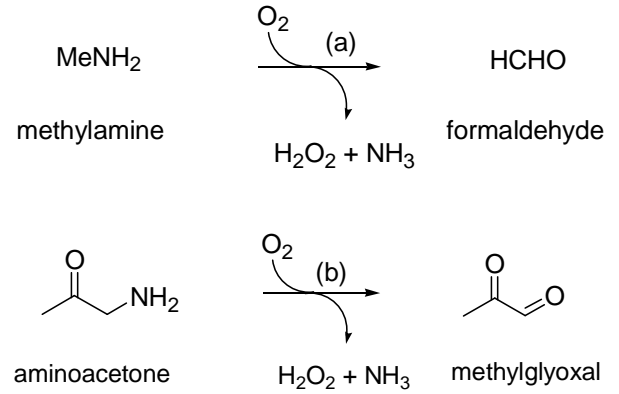

Scheme 4 
Scheme 5

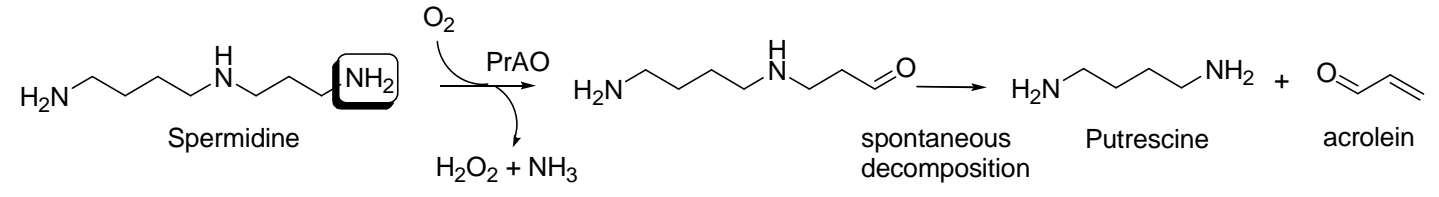

Scheme 5 


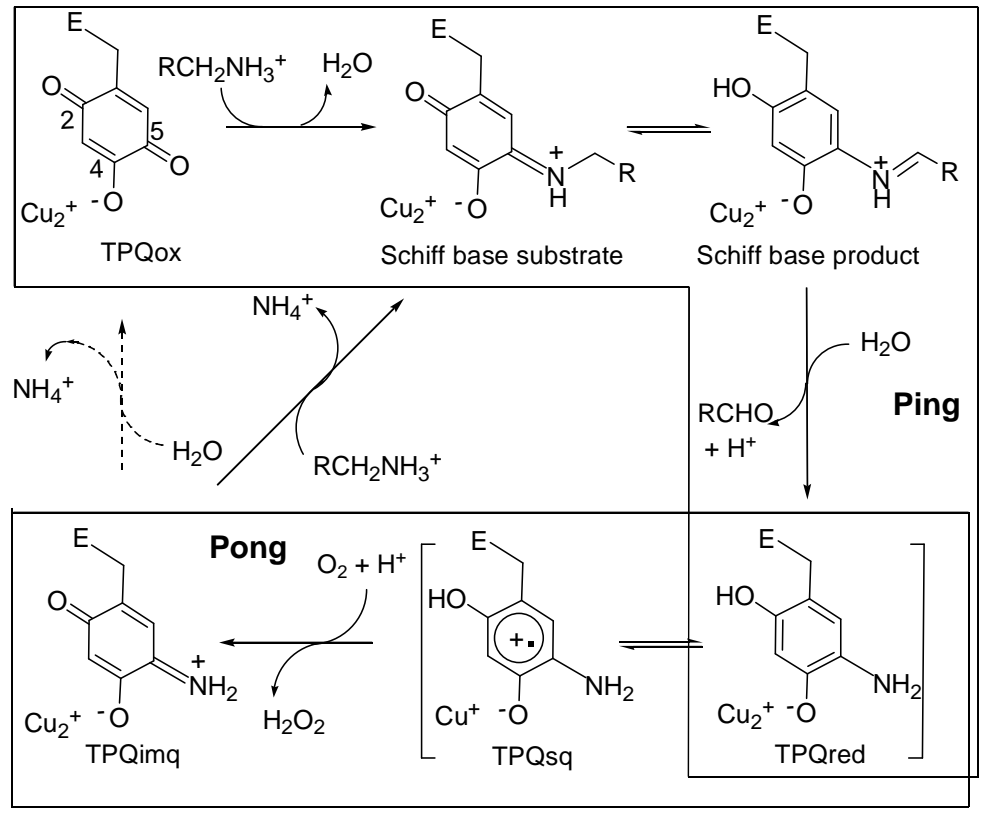

sq: semiquinone; imq: iminoquinone

Scheme 6 


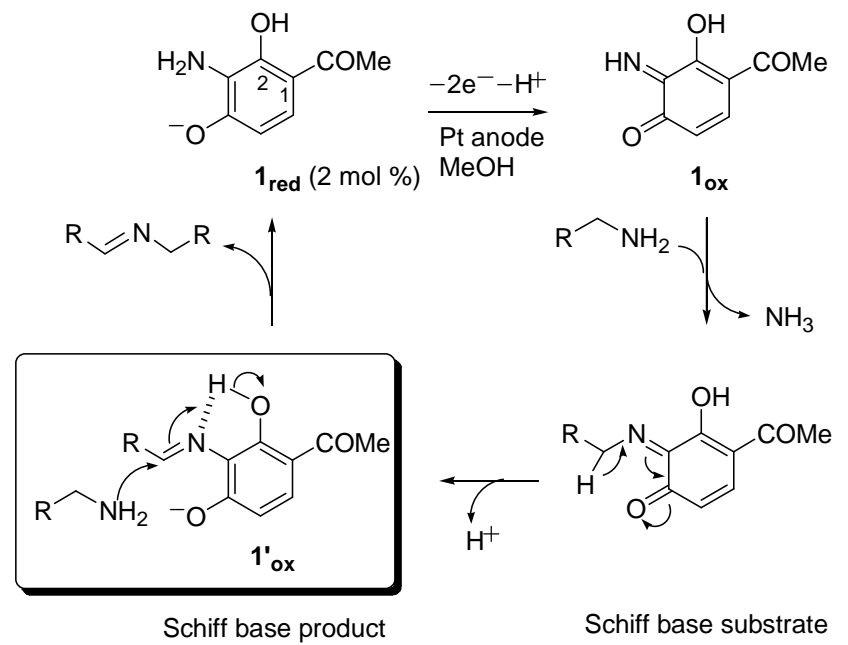

Scheme 7 


\section{*Detailed Response to Reviewers / Reponse aux lecteurs}

\section{Response to reviewer 1}

Modifications are indicated in yellow in the manuscript

Point 1. Detailed descriptions of figure and schemes are now included.

Point 2. Physiological observations that the activities of $\mathrm{CuAOs}$ are increased in some human diseases have been made in plasma. So, plasma is now indicated in the manuscript page 8 . 


\section{Réponse aux commentaires du rapporteur 2}

Les modifications sont indiquées en jaune dans le manuscrit

Point 1. Les abréviations demandées ont été insérées.

Point 2. Le schéma 1 a été corrigé

Point 3. La légende du tableau a été modifiée comme suit :

Selective inhibition of LJP 1586 for PrAOs

Inhibition sélective de LJP 1586 pour les PrAOs

Point 4. Les références 50, 51, 60 et 67 ont été corrigées. 